Communication

\title{
Virus and Potential Host Microbes from Viral-Enriched Metagenomic Characterization in the High-Altitude Wetland, Salar de Huasco, Chile
}

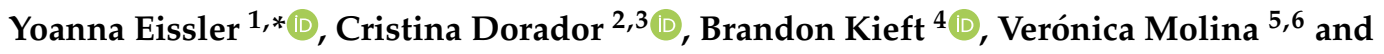 \\ Martha Hengst ${ }^{3,7}$ (D) \\ 1 Instituto de Química y Bioquímica, Facultad de Ciencias, Universidad de Valparaíso, Gran Bretaña 1111, \\ Playa Ancha, Valparaíso 2360102, Chile \\ 2 Laboratorio de Complejidad Microbiana y Ecología Funcional, \\ Instituto de Antofagasta \& Departamento de Biotecnología, \\ Facultad de Ciencias del Mar y Recursos Biológicos, Universidad de Antofagasta, \\ Avenida Universidad de Antofagasta s/n, Antofagasta 1240000, Chile; cristina.dorador@uantof.cl \\ 3 Centre for Biotechnology and Bioengineering, Universidad de Chile, Beaucheff 851 (Piso 7), \\ Santiago 8320000, Chile; mhengst@ucn.cl \\ 4 Lab of Dr. Steven Hallam, University of British Columbia, Vancouver, BC V6T 1Z4, Canada; \\ kieft1bp@gmail.com \\ 5 Departamento de Biología, Observatorio de Ecología Microbiana, Facultad de Ciencias Naturales y Exactas, \\ Universidad de Playa Ancha, Avenida Leopoldo Carvallo 270, Playa Ancha, Valparaíso 2340000, Chile; \\ veronica.molina@upla.cl \\ 6 HUB Ambiental UPLA, Universidad de Playa Ancha, Avenida Leopoldo Carvallo 200, Playa Ancha, \\ Valparaíso 2340000, Chile \\ 7 Departamento de Ciencias Farmacéuticas, Facultad de Ciencias, Universidad Católica del Norte, \\ Av Angamos 0610, Antofagasta 1270709, Chile \\ * Correspondence: yoanna.eissler@uv.cl; Tel.: +56-32-250-8063
}

Received: 24 June 2020; Accepted: 3 July 2020; Published: 20 July 2020

\begin{abstract}
Salar de Huasco is a wetland in the Andes mountains, located $3800 \mathrm{~m}$ above sea level at the Chilean Altiplano. Here we present a study aimed at characterizing the viral fraction and the microbial communities through metagenomic analysis. Two ponds ( $\mathrm{H} 0$ and $\mathrm{H} 3$ ) were examined in November 2015. Water samples were processed using tangential flow filtration to obtain metagenomes from which the DNA fraction of the sample was amplified and sequenced (HiSeq system, Illumina). The ponds were characterized by freshwater and the viral-like particles to picoplankton ratio was 12.1 and 2.3 for $\mathrm{H} 0$ and $\mathrm{H} 3$, respectively. A great number of unassigned viral sequences were found in $\mathrm{H} 0(55.8 \%)$ and $\mathrm{H} 3(32.8 \%)$, followed by the family Fuselloviridae $20.8 \%$ (H0) and other less relatively abundant groups such as Microviridae (H0, 11.7\% and H3, 3.3\%) and Inoviridae (H3, 2.7\%). The dominant viral sequences in both metagenomes belong to the order Caudovirales, with Siphoviridae being the most important family, especially in H3 (32.7\%). The most important bacteria phyla were Proteobacteria, Bacteroidetes and Firmicutes in both sites, followed by Cyanobacteria (H0). Genes encoding lysogenic and lytic enzymes (i.e., recombinases and integrases) were found in HO and $\mathrm{H} 3$, indicating a potential for active viral replication at the time of sampling; this was supported by the presence of viral metabolic auxiliary genes at both sites (e.g., cysteine hydrolase). In total, our study indicates a great novelty of viral groups, differences in taxonomic diversity and replication pathways between sites, which contribute to a better understanding of how viruses balance the cycling of energy and matter in this extreme environment.
\end{abstract}

Keywords: virus; metagenome; bacteriophage; high-throughput sequencing; archaea; bacteria; high-altitude wetland; microbial diversity; freshwater 


\section{Introduction}

Wetlands play an important role in many ecological contexts, including climate change, biodiversity, hydrology, and human health [1]; unfortunately, these ecosystems are constantly threatened by human activities [2,3]. As of 2009, 33\% of global wetlands had been lost [4], hence their study is highly necessary. Salar de Huasco is a salt-flat or Salar in local language, located in the Chilean altiplano and classified as a high-altitude wetland under the Ramsar convention since 1996. Despite this denomination, it is subjected to human impact by tourism and mining activities, underlining the importance of performing baseline studies of the natural ecology of this wetland.

This ecosystem presents a large variety of environments, from transient ponds and streams to a main lake where flamingos and llamas cohabitate among other species [5]. This wetland also harbors a high microbial biodiversity [6,7] with a very active microbial community [8,9] that is adapted to extreme physicochemical conditions such as extensive daily temperature ranges ( -15 to $\left.20{ }^{\circ} \mathrm{C}\right)$ [10], intense irradiation (up to $1125 \mathrm{~W} / \mathrm{m}^{2}$ ) [8], high evaporation rates $(1260 \mathrm{~mm} /$ year) versus low precipitation rates $\left(150 \mathrm{~mm} \mathrm{y}^{-1}\right)$ and a high variation in salinity conditions, from freshwater to hypersaline [11]. Bacteria communities are dominated by Bacteroidetes, Proteobacteria, Actinobacteria and Cyanobacteria among others $[5,7,12,13]$. Archaea are represented by Euryarchaeota, Crenarchaeota, Diapherotrites, Thaumarchaeota, and Woesearchaeota as the predominant phyla $[7,13,14]$.

Concomitant with strong ecosystem variability and high prokaryote diversity, viral communities in the wetland are also expected to be widespread and diverse and play a pivotal role in ecosystem function. Viruses are the most abundant entities in the biosphere and have the potential to infect all domains of life, producing diseases, influencing biogeochemical cycles, facilitating gene transfer, and affecting the course of microbial evolution. One important mechanism of viral impact on the diversity and function of microbial populations is through the incorporation of auxiliary metabolic genes (AMGs) [15], which may modulate cellular activity by expressing enzymes that participate in C, N, P and S metabolic pathways [16-19].

Viral abundance is ecosystem-dependent and fluctuates from $10^{3}$ to over $10^{9}$ viruses $\mathrm{mL}^{-1}$ [20-22]. For instance, in freshwater and saline environments, the average of virus-like particles (VLP) $\mathrm{mL}^{-1}$ is $7.00 \times 10^{7}$ and $4.99 \times 10^{8}$, respectively, with a virus to picoplankton abundance ratio (VPR) ranging from 0.01 to 267.2 and 0.2 to 144.8 [21]. The only study conducted in the Altiplano area addressing viruses as modulators of the active microbial community is from Salar de Huasco [13]. This study covered from freshwater to saline habitats, where values for viral abundance $\left(8.44 \times 10^{5}\right.$ to $\left.4.78 \times 10^{8} \mathrm{VLP} \mathrm{mL}^{-1}\right)$ and VPR ( 2 to 351 ) represented the upper range of, or were even higher than, those found in other freshwater and saline environments.

Similar to oceanic, brackish or freshwater ecosystems, bacteriophage represent the largest group of viruses in wetlands $[20,23]$. Caudovirales is the most common order among dsDNA viruses found in wetlands $[24,25]$, and studies conducted in high-altitude wetlands in China isolated and characterized several bacteriophages within the Caudovirales order and the families Myoviridae [26], Siphoviridae [27] and Podoviridae [28].

Nevertheless, overall, little is known about viral community composition in high-altitude wetlands despite the improvement in high-throughput environmental DNA sequencing techniques that have allowed for viral classification through bioinformatic methods $[29,30]$. Here we examine two viral-enriched metagenomes from freshwater ponds in a high-altitude wetland and classify DNA viruses, identify potential new bacteriophage and their putative hosts, describe genes encoding enzymes related to the lytic and lysogenic cycles, and classify AMGs related to metabolic pathways of the biogeochemical cycles in Salar de Huasco wetland. As a first report in viral genomic characterization in this habitat, our results emphasize the need to complement studies of bacteria and archaea communities with viral community characterization in order to understand microbe-driven elemental cycles in Salar de Huasco. 


\section{Materials and Methods}

\subsection{Sampling Sites}

Sampling took place in Salar de Huasco (3800 m a.s.l), Chile, during dry season in 10 November 2015,

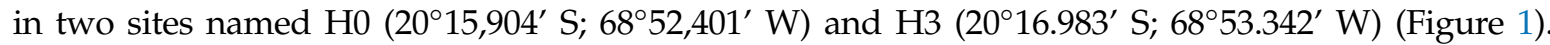
$\mathrm{H} 0$ corresponded to a transient pond of approximately $30 \mathrm{~cm}$ deep and H3 to a stream connected to one of the spring waters that feed the Salar (Figure 1).
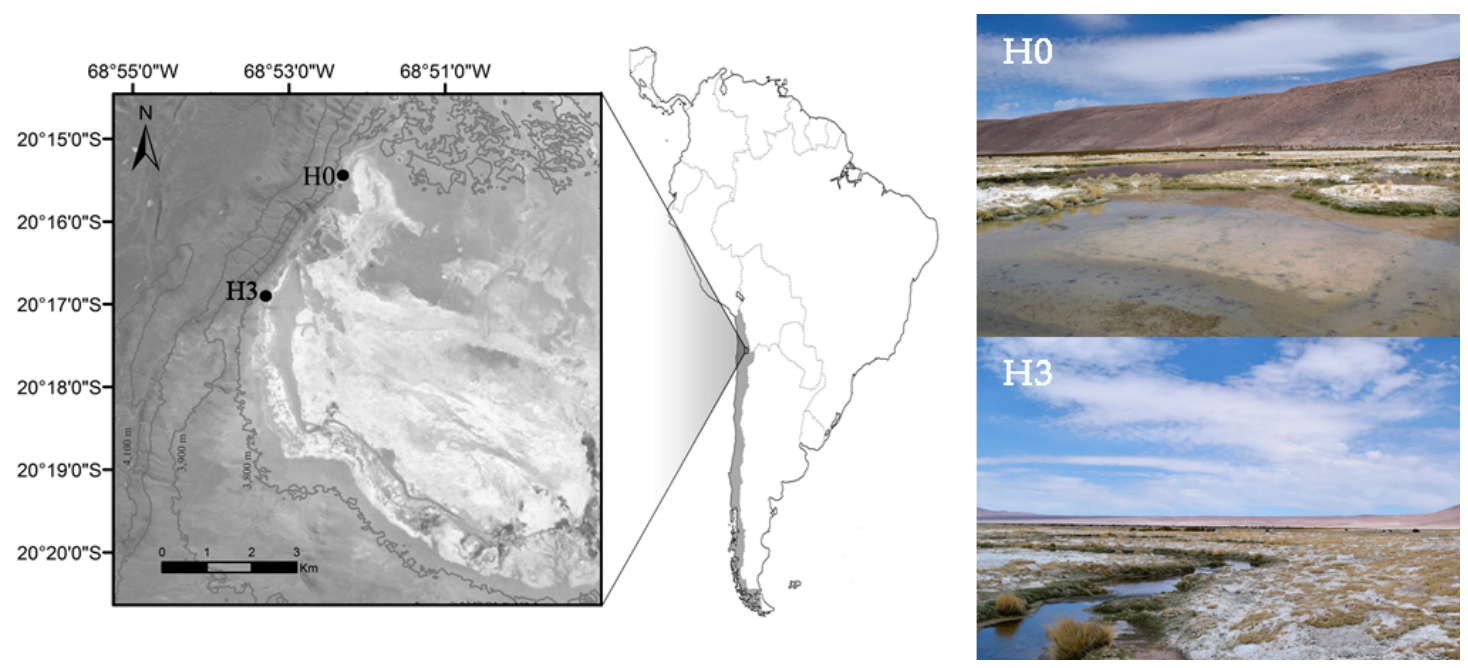

Figure 1. Map of Salar de Huasco, Chile, showing the location of both sampling sites (i.e., H0 pond and H3 stream) sampled during dry season in 10 November 2015.

\subsection{Sample Collection and Processing}

Water temperature, conductivity, $\mathrm{pH}$, and oxygen were measured in situ using a multiparameter Thermo Scientific Orion Star Multiparameter (model A329). Samples for phosphate analysis were frozen until processing using standard colorimetric methods with a nutrient automatic analyzer according to [31]. Samples $(15 \mathrm{~mL})$ for picoplankton and viral abundance were collected from each site and analyzed through the epifluorescence method [32]. Briefly, water was fixed with glutaraldehyde (1\% final concentration) and stored frozen until analyses. Viral samples were first prefiltered with a Syringe Filter Unit, $0.22 \mu \mathrm{m}$, polyethersulfone (Millex_GP, Millipore ${ }^{\circledR}$, Darmstadt, Germany) and then filtrated onto a $25 \mathrm{~mm}, 0.02 \mu \mathrm{m}$ pore-size Anodisc membrane filters (Whatman ${ }^{\circledR}$, Buckinghamshire, UK) at $130 \mathrm{~mm} \mathrm{Hg}$ pressure. Filters were placed in the bottom of a Petri dish in darkness and stained for 15 min with $100 \mu \mathrm{L}$ of SYBR ${ }^{\mathrm{TM}}$ Gold Nucleic Acid Gel Stain (10,000×; Invitrogen ${ }^{\mathrm{TM}}$, Carlsbad, CA, USA) diluted to a final concentration of $2 \times$ in filtered $0.02 \mu \mathrm{m}$ molecular biology grade water. Filters were then blotted on a Kimwipe ${ }^{\circledR}$ (Kimtech ${ }^{\text {science }}$, Little Rock, AR, USA) to remove excess fluid and then mounted between a glass slide and coverslip. Picoplankton abundance was estimated following the same protocol described above for viral abundance, but without prefiltering the sample and using a $0.2 \mu \mathrm{m}$ pore-size Anodisc membrane filter (Whatman ${ }^{\circledR}$, Buckinghamshire, UK). Ten to twenty fields were randomly selected and more than 100 VLP or picoplanktonic cells were counted per slide at 1000× using an Olympus BX60F-3 epifluorescence microscope, equipped with a HBO 50 W mercury lamp (excitation wavelength 460-490 nm, cutoff filter $515 \mathrm{~nm}$ ).

To process water samples, tangential flow filtration (TFF) was used [33]. First, in order to remove large particles for TFF, 5-10 L of water underwent serial filtrations at $100 \mu \mathrm{m}$ and $25 \mu \mathrm{m}$ using nylon fiber sieves, then through a $0.22 \mu \mathrm{m}$ Millipore ${ }^{\circledR}$ Sterivex ${ }^{\mathrm{TM}}$ filter unit polyethersulfone membrane. To enrich the samples in virus-like particles (VLP), a $30 \mathrm{kDa}$ spiral-wound TFF filter (Amicon S10Y30; Millipore ${ }^{\circledR}$, Darmstadt, Germany) was used, followed by polyethylene glycol 8000 (Sigma-Aldrich, St. Louis, MI, USA) precipitation [34]. Then, the samples were treated with nucleases (2.5 U of DNase 
and $0.25 \mathrm{U}$ of RNase) for $3 \mathrm{~h}$ at $37^{\circ} \mathrm{C}$ to eliminate nucleic acids not encapsulated in viral capsids. Subsequently, a DNA extraction kit (ZR Viral DNA Kit ${ }^{\mathrm{TM}}$, Irvine, CA, USA) was used following the manufacturer's instructions to extract viral DNA from capsids. The DNA obtained was quantified using a spectrophotometer (MaestroNano ${ }^{\circledR}$, Maestrogen, Taiwan), and the genomic material was subject to non-specific amplification [35] using the GenomiPhi ${ }^{\mathrm{TM}}$ V2 DNA amplification Kit (Illustra ${ }^{\mathrm{TM}}$, GE Healthcare, Chicago, IL, USA) in order to obtain DNA concentrations required for sequencing. QIAamp ${ }^{\circledR}$ DNA mini kit (QIAGEN ${ }^{\circledR}$, Valencia, CA, USA) was used to further purify the DNA according to the manufacture's protocol. Before sample sequencing, final DNA concentration was measured with MaestroNano ${ }^{\circledR}$ spectrophotometer.

\subsection{Sequencing and in Silico Analysis}

The two DNA preparations were sequenced via Mr DNA-Texas service, using a HiSeq 2500 system (Illumina, USA). The paired-end reads from both $\mathrm{H} 0$ and $\mathrm{H} 3$ metagenomes were checked using the quality control of BaseSpace (https://basespace.illumina.com); these procedures yielded 11,614,382 reads totaling 2,558,493,699 base pairs (bps) with an average length of 220 bps (H0), and 10,096,566 reads totaling 2,230,955,051 bps with an average length of $221 \mathrm{bps}$ (H3). Raw reads were submitted as forward and reverse fastq compressed files to the National Center for Biotechnology Information (NCBI) Sequence Read Archive (SRA) https://submit.ncbi.nlm.nih.gov/subs/sra/; the SRA BioProject number is PRJNA613071 and BioSample numbers are SAMN14395755 and SAMN14395756 for H0 and H3 raw reads, respectively.

Quality filtering was performed using Trimmomatic software Version 0.36 [36], with a quality cutoff score of 30 and a minimum length set at 50 . The filtered sequences were assembled and contigs were obtained using SPAdes-3.11.1 [37] software in metaSPAdes mode with assembly parameters $k:(21,33,55)$ and default settings. This Whole Genome Shotgun project has been deposited at DDBJ/ENA/GenBank under the accession JABXJQ000000000 and JABXJR000000000. The version described in this paper is version JABXJQ010000000 and JABXJR010000000 for H0 and H3 metagenomes, respectively.

Open reading frames (ORFs) and their location on all assembled contigs were predicted using the Prodigal software [38]. Quality-filtered paired-end reads were aligned to ORFs using bowtie2 [39]. Abundance values were calculated for each ORF based on read mapping using the transcripts per million (TPM) calculation [40]. Although this method was originally developed for cDNA transcripts, we applied the TPM calculation to DNA reads here in order to normalize ORF abundances by (1) predicted ORF length (in kilobase-pairs) and (2) library size (total DNA sequencing depth); this accounts for differences in these measures between $\mathrm{H} 0$ and $\mathrm{H} 3$. Thus, our TPM method resulted in an abundance metric of ORF-mapped metagenome reads per million reads in each sample. For ORF taxonomic and functional annotations, taxonomic accession numbers were assigned to ORFs using a diamond homology [41] search against the RefSeq protein database. The NCBI program entrez was used to assign taxonomy to accession numbers. Functional annotations for ORFs were made using the ghostKOALA tool [42] against the KEGG orthology database. Metagenome gene (ORF) TPM abundances were summed by their unique taxonomic string identifier (domain, phylum, class, order, family, genus, species) and used as the count table (in place of a standard OTU table) to estimate richness and alpha-diversity using the 'vegan' $R$ package [43].

In order to compare the sequence identity of taxonomically unassigned contigs between the metagenomes (i.e., the similarity of the unannotated populations), first we chose contigs with no genes that could be assigned to a taxonomic group at the phylum level (i.e., either only domain was known or there was no classification at all). We used a sliding k-mer window of $31 \mathrm{bps}$ along each contig to compare it (pairwise) to every other unassigned contig in both metagenomes. If two contigs had a Jaccard similarity index of $>0.1$ in k-mer space they were counted as "similar" (biologically, it was assumed they came from the same or a related population).

The assembled sequences were examined using Virsorter [29] to identify the function and phylogeny of viruses within the assembled metagenomes. For this, the platform CyVerse Discovery 
Environment (https://de.cyverse.org/de/) was used to run the application VirSorter 1.0.3 with the viromes database and decontamination mode. A list of contig sequences predicted as viral was obtained and organized by category from 1 to 6 (Tables S1 and S2). Here, we manually examined (Bioedit 7.2.6.1) and annotated the more confident viral predictions (categories 1-Pretty sure and 2-Quite sure) by using blastn suite online tool (https://blast.ncbi.nlm.nih.gov/). For H0 and H3, 299 and 217 nodes were manually examined, respectively. As a second and complementary approach, the program VIBRANT (v1.0.1) was used to predict viral contigs among all metagenome contigs [30]. In this unsupervised method, VIBRANT recovered 661 and 355 viral contigs from $\mathrm{H} 0$ and H3 assemblies, respectively (Tables S3 and S4), and flagged dozens of potential auxiliary metabolic genes (AMGs) on viral contigs.

\section{Results and Discussion}

Both $\mathrm{H} 0$ and $\mathrm{H} 3$ sites were characterized by low salinity, alkaline, and oxygenated water. Salinity was in the range of fresh water according to [44], which characterizes water sources as fresh when conductivity is $<800 \mu \mathrm{S} \mathrm{cm}{ }^{-1}$ (Table 1). These chemical characteristics were similar to those sampled during February 2012, November 2014 and March 2015 in Salar de Huasco [13,45]. VLP and picoplankton abundance were very similar in the H0 and H3 sites while VPR was slightly higher in H0 (Table 1). These values were lower than the ones observed in wet season, February 2012 [13] where the order of magnitude for VLP and picoplankton abundance was $10^{7}-10^{8} \mathrm{VLP} \mathrm{mL}^{-1}$ and $10^{5}-10^{6}$ cells $\mathrm{mL}^{-1}$, and the VPR was 67 and 2 for $\mathrm{H} 0$ and $\mathrm{H} 3$, respectively. Instead, during the sampling in November 2014 and March 2015, VLP $\left(10^{5} \mathrm{VLP} \mathrm{mL}^{-1}\right)$ and picoplankton $\left(10^{4}-10^{5}\right.$ cells $\left.\mathrm{mL}^{-1}\right)$ abundance was lower than the ones report here, but VPR were similar to H0 (i.e., 9.4 and 13.2 for $\mathrm{H} 0$ spring and H3 spring, respectively) [45]. As reported in [13], where microbial mats were present, a higher abundance of picoplankton and VLP was observed, and this was also associated with higher microbial diversity and community complexity in ponds when compared with water sources or lagoon sites. During our study, microbial mats were scarce or not present at all, which might contribute to the lower abundance that was observed for viruses and picoplankton cells and the lower VPR.

Table 1. Physicochemical parameters, viral, picoplankton abundance and virus to picoplankton ratio (VPR) determined for both sites.

\begin{tabular}{|c|c|c|c|c|c|c|c|c|}
\hline Site & $\begin{array}{l}\text { Conductivity } \\
\left(\mu \mathrm{S} \mathrm{cm} \mathrm{cm}^{-1}\right)\end{array}$ & $\begin{array}{c}\text { Water } \\
\text { Temperature } \\
\left({ }^{\circ} \mathrm{C}\right)\end{array}$ & $\mathrm{pH}$ & $\begin{array}{c}\text { Dissolved } \\
\text { Oxygen } \\
\left(\mathrm{mg} \mathrm{L}^{-1}\right)\end{array}$ & $\begin{array}{l}\text { Phosphate } \\
\left(\mathrm{mg} \mathrm{L}^{-1}\right)\end{array}$ & $\begin{array}{c}\text { Virus } \\
\left(\text { VLP } \mathrm{mL}^{-1}\right)\end{array}$ & $\begin{array}{l}\text { Picoplankton } \\
\text { (cells } \mathrm{mL}^{-1} \text { ) }\end{array}$ & VPR \\
\hline Ho & 566.3 & 19.3 & 8.87 & 14.56 & 0.081 & $2.5 \times 10^{6}$ & $2.1 \times 10^{5}$ & 12.1 \\
\hline H3 & 580.7 & 17.6 & 8.68 & 8.32 & 0.090 & $1.3 \times 10^{6}$ & $5.3 \times 10^{5}$ & 2.3 \\
\hline
\end{tabular}

Overall, VLP and picoplankton abundance values found in H0 and H3 during November 2015 were in the same range as those in other similar freshwater ecosystems $[20,21,46]$. Notably, however, a recent review [21] found an average of $7 \times 10^{7} \mathrm{VLP} \mathrm{mL}^{-1}(n=223)$ and $1.33 \times 10^{7} \mathrm{cells} \mathrm{mL}^{-1}(n=211)$ in freshwater ecosystems, which is higher in comparison to our results. Generally, high VPR values are related to high viral dynamics, low prokaryotic production, and/or high VLP abundance, and the ratio usually falls between 3 and 10 in aquatic ecosystems [20,46]. However, [21] reported an average of $17.2(n=299)$ for freshwater environments, suggesting that the lower VPR values observed in this study could indicate higher VLP loss or presumably higher microbial production. High viral losses have been associated with human activities, which can introduce chemicals and clays into the water that remove virus particles [47]. Salar de Huasco, despite it being a remote area, is still impacted by human activities; there is one small native family living close by that have livestock (llamas), and the area receives tourism traffic as well as mining exploration. Bacterial secondary production in this high-altitude wetland has been reported to be high [48] in comparison to other high-altitude lakes located in Europe [49-51]. Supporting these findings, Molina et al., (unpublished work) reported high secondary production in a pond located near H3 in November 2015, with values ranging from 2.56 to 
$4.24 \mu \mathrm{gC} \mathrm{L} \mathrm{L}^{-1} \mathrm{~h}^{-1}$ (data unpublished). Thus, the drivers of lower VPR ratios found in this study may be manifold, although the mechanisms were not directly tested.

\subsection{Metagenome Composition}

Total taxonomic community composition (including both VLP and microbial populations) based on gene abundance (TPM) was markedly different between the two sites (Figure 2). H0 had a distinctly lower relative abundance of Proteobacteria than H3, but a much higher abundance of other Bacterial groups such as Bacteroidetes, Firmicutes, and Cyanobacteria. Total gene abundance in the H0 community was composed of over 5\% Archaea and nearly 5\% Eukaryotic populations, while in $\mathrm{H} 3$ the Archaea were represented at $<0.05 \%$ and the Eukaryotes at $<1 \%$.

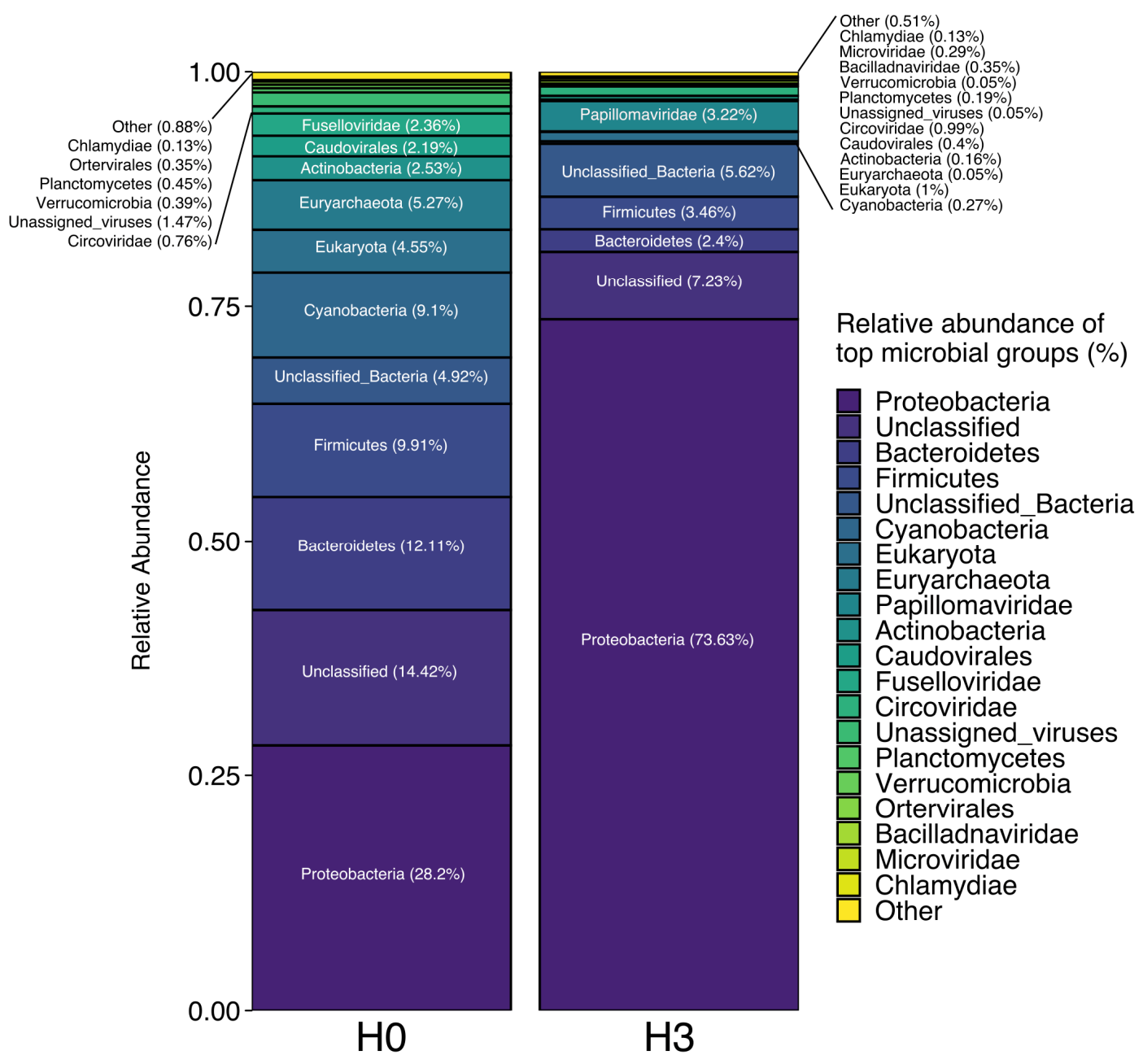

Figure 2. Total community taxonomic bar plot for $\mathrm{H} 0$ and $\mathrm{H} 3$ metagenomes.

In general, the microbial community composition reported here is comparable with previous studies conducted in high-altitude wetlands $[6,14]$. In particular, a diversity survey carried out previously in three different ponds in Salar de Huasco [12] supports the dominance of Proteobacteria, Cyanobacteria and Bacteroidetes as core phyla present in all ponds, with Proteobacteria representing the majority of the prokaryotic community [12]. In our study we found a large difference in representation of Cyanobacteria between $\mathrm{H} 0(9.1 \%)$ and $\mathrm{H} 3(0.27 \%)$, in contrast to what was observed by [13], when Cyanobacteria were more highly represented in H3 than in H0. Interestingly, cyanophages were in low relative abundance in both sites but over twice as prevalent in $\mathrm{H} 3$, suggesting that virus-host dynamics might be influencing Cyanobacteria abundance over time in the ponds. Molina et al. [45] reported the three main abundant phyla of bacteria as Proteobacteria, Cyanobacteria and Bacteroidetes, and the 
abundant Archaeal phyla as Crenarchaeota, Parvarchaeota and Euryarchaeota based on 16S rDNA gene sequences. In contrast to our similar results for bacterial populations, these Archaeal phyla were relatively rare during November 2014 and March 2015 for $\mathrm{H} 0$ and $\mathrm{H} 3(<0.72 \%)$. Abundance may not be a strong indicator of importance, however, as when the active microbial community was studied using cDNA, the relative abundance of Archaea was much higher, reaching up to $30 \%$ and $70 \%$ in $\mathrm{H} 0$ and H3, with a greater contribution of Euryarchaeota and Thaumarchaeota phyla, respectively [13].

Supporting the patterns of taxonomic relative abundance presented in both sites, greater diversity and evenness was observed in $\mathrm{H} 0$ compared to H3 (Table 2). These observations are comparable to what was previously reported for pond sites in the same area during previous studies $[13,45]$, where the highest alpha diversity indexes (i.e., Shannon index) were observed in ponds compared to waterways. Using a k-mer sequence similarity measure, we calculated that only $12.2 \%$ of contigs in the "unclassified" category from Figure 2 were shared between metagenomes, further highlighting the different in community composition between these two sites.

Table 2. Metagenome richness and Alpha diversity indexes, including bacteria, archaea and viral diversity.

\begin{tabular}{ccccc}
\hline Site & Observed & Shannon & Chao1 & Evenness \\
\hline H0 & 2209 & 4.381 & 2346.1 & 0.00198 \\
H3 & 1905 & 3.289 & 1918.5 & 0.00173 \\
\hline
\end{tabular}

\subsection{Viral Genome Composition}

Within the viral community identified by VIBRANT, each site appeared to host a distinct set of viral groups (Figure 3). Over half of viral contigs in the H0 community could not be assigned to a known group based on sequence homology, while only a third of viral sequences in the H3 community were unassigned. Since we did not recover enough DNA outright after sample processing, we used the multiple displacement amplification (MDA) method [35]. This random amplification technique requires attention while interpreting results, since it has some bias such as chimera formation [52], which could be interpreted as a novel sequence while in fact it is an artifact. Therefore, the percentage of unassigned sequences found in the sampling sites (Figure 3) might be overestimated. Unfortunately, there are no previous studies to compare viral diversity in high-altitude wetlands for the Altiplano area, but based on results of the prokaryotic community in our study and in others, there were a significant number of unclassified taxa, up to $56 \%$ in some cases $[6,13,14,45]$, suggesting a high number of novel microbial groups and their viruses that are yet to be characterized.

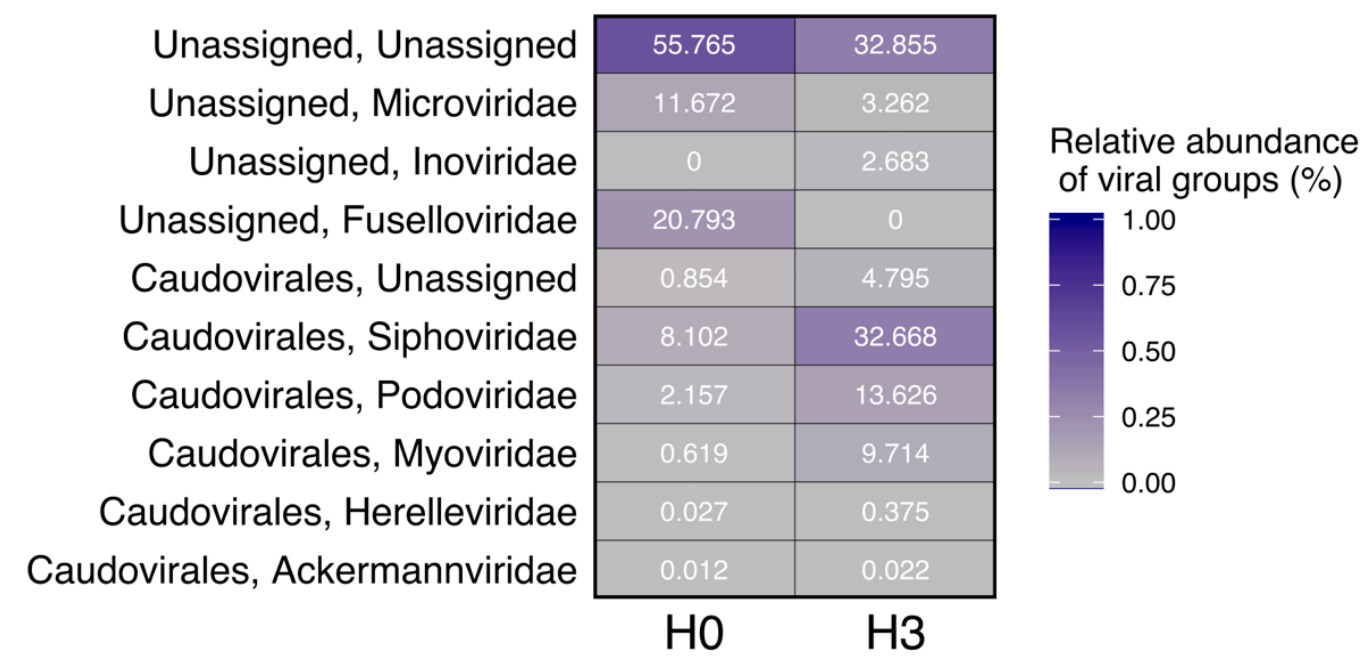

Figure 3. Viral taxonomy heatmap generated with VIBRANT. 
Viral groups with strong differences in relative abundance between the sites included Inoviridae, Microviridae, Fuselloviridae, and several Caudovirales groups. Some putative hosts could be identified or inferred for these phage taxa, although the low resolution of viral phylogenetic assignment and the diverse nature of viral genomes provided only a coarse-scale putative host range identification in most cases (Table 3). When metagenomes are analyzed by sequence homology, the dependency of available sequences in databases must be taken into account; so far there is a very limited number of well-characterized viral species, most of them bacteriophage, and within this group there are also bias to dsDNA and Mycobacteriophage [53]. This could easily explain why there are mostly bacteriophage identified sequences through Virsorter and VIBRANT in our study, limiting comparison to only annotated viral sequences. A review that analyzed 12 freshwater metaviromes showed that viral sequences able to be identified were as low as $5.3 \%$ to $29.5 \%$ and the majority belong to phage that prey on bacteria [53].

Notably, one viral group targeting Archaea, the Fuselloviridae, had strikingly higher relative abundance in H0, corollary to the higher representation of its host domain Archaea at that site. This family of viruses infects mainly Sulfolobus sp. which belong to the phyla Crenarchaeota that have been previously characterized in H0 [46]. Furthermore, some other reports [54] show that Haloarchaea class members (phylum Euryarchaeota) may be hosts of crenarchaeal fuselloviruses, which were found to be very abundant in earlier studies in $\mathrm{HO}[7,14]$.

In accordance with the higher relative abundance of Proteobacteria in H3, the abundance of several Caudovirales groups that most likely specialize in populations in the Proteobacteria phylum was much higher in the H3 metagenome. Table 3 also shows the identification of one viral sequence (7268 bps, $92 \%$ identity) in $\mathrm{H} 3$ belonging to Siphoviridae, which putative host is Actinobacteria. This phylum is only represented in $\mathrm{H} 3$ by a very small percentage $(0.16 \%)$ and has also been reported before as a rare group in this wetland [45]. Microviridae, a family of bacteriophages with a single-stranded DNA genome, was relatively abundant among the assigned sequences, represented in $\mathrm{H} 0$ at $11.67 \%$ and in $\mathrm{H} 3$ at $3.26 \%$. Single-stranded DNA viruses have been reported for freshwater ecosystems such as lakes [25] and the artic [24], but are not always well represented, like in the largest freshwater lake in Ireland where they constituted less than 1\% of the virome [55]. In a thorough review of the literature we did not find metaviromes references from high-altitude freshwater wetlands for many viral sequences or groups that we identified, so it is not possible to provide an in-depth comparative analysis in this study.

\subsection{Functional Analysis of Viral Sequences}

We expected that differences in phylogenetic representation of several ecologically important phage groups between the two sites would translate to a difference in the overall functional potential of the virome between samples. Based on the relative abundance of genes identified as viral in origin (by VIBRANT, measured as TPM), functional profiles of the $\mathrm{H} 0$ and $\mathrm{H} 3$ viral communities were highly distinct (Figure 4). Two recombinase genes (xerD and spolVCA) had the highest representation of all functions in $\mathrm{H} 0$. Interestingly, these genes were also recovered from $\mathrm{H} 3$ but at very low abundance compared to $\mathrm{H0}$; this may indicate that a highly active phase of the lytic or lysogenic cycle was occurring during sampling from the $\mathrm{H} 0$ community since recombinase/integrase genes play an important role in integrating or excising viral DNA from a host genome [56]. Two functions strongly represented in the $\mathrm{H} 3$ viral community but not in $\mathrm{H} 0$ included enzymes responsible for cellular disruption (an amidase and a hydrolase), specifically, $\mathrm{N}$-acetylmuramoyl-L-alanine amidase Rv3717, which is a cell-wall hydrolase that hydrolyzes the amide bond between $\mathrm{N}$-acetylmuramic acid and L-alanine in cell-wall glycopeptides (UniProtKB - I6Y4D2). It may also be involved in the peptidoglycan degradation pathway $[57,58]$, which is part of the cell wall degradation of several bacteria that occurs during a lytic cycle. In addition, $\mathrm{H} 0$ presented genes for the phage replication initiation protein and $\mathrm{H} 3 \mathrm{did}$ not (Figure 4), supporting the idea that one of the viral replication mechanisms was more predominant than the other; thus, lysogeny and lytic infections would be more dominant in $\mathrm{HO}$ and $\mathrm{H} 3$, respectively. 
Table 3. Viral genome composition and structure diversity in according to Virsorter and VIBRANT.

\begin{tabular}{|c|c|c|c|c|c|c|c|}
\hline Site & $\begin{array}{l}\text { Node and } \\
\text { Category }\end{array}$ & Size $(b p)^{1}$ & $\begin{array}{l}\text { Genome } \\
\text { Structure }\end{array}$ & Features & Virus Group & Putative Host & $\begin{array}{l}\text { VIBRANT ID; } \\
\text { Viral Gene TPM }\end{array}$ \\
\hline $\mathrm{H} 0$ & 278 and 1 & $8640(3748)$ & linear & $\begin{array}{l}\text { phage tail protein, phage tail } \\
\text { tape measure protein, phage } \\
\text { tail assembly protein, phage } \\
\text { major tail tube protein }\end{array}$ & $\begin{array}{l}\text { Caudovirales, Myoviridae, Serratia } \\
\text { phage KSP20, 83.37\% identity }\end{array}$ & $\begin{array}{l}\text { Proteobacteria, } \\
\text { Gammaproteo-bacteria } \\
\text { (Enterobacteriaceae) }\end{array}$ & $\begin{array}{l}\text { Peduovirinae; } \\
28.39\end{array}$ \\
\hline $\mathrm{HO}$ & $\begin{array}{l}332,581 \\
2647 \text { and } 1\end{array}$ & $\begin{array}{l}8085(3895), 6031 \\
(2339), 2399(1105)\end{array}$ & linear & several hypothetical proteins & $\begin{array}{l}\text { Myovirus (Uncultured Caudovirales } \\
\text { phage clone similar to Pseudomonas } \\
\text { phage), } 72-81.45 \% \text { identity }\end{array}$ & $\begin{array}{l}\text { Proteobacteria, } \\
\text { Gammaproteo-bacteria } \\
\text { (Pseudomonas sp.) }\end{array}$ & $\begin{array}{l}\text { Peduovirinae; } \\
12.07 \\
\text { Peduovirinae; } \\
\text { 32.26 Siphoviridae; } \\
\quad 6.68\end{array}$ \\
\hline $\mathrm{HO}$ & 5894 and 1 & $1425(414,268)$ & linear & $\begin{array}{l}\text { terminase, portal protein, } \\
\text { terminase large subunit }\end{array}$ & $\begin{array}{l}\text { Siphoviridae (Arthobacter phage } \\
\text { Gordon and Streptomyces phage), } \\
69.74 \% \text { and } 67.52 \% \text { identity }\end{array}$ & Actinobacteria & Too short; NA \\
\hline $\mathrm{H} 3$ & 114 and 1 & 15881 (6652) & linear & $\begin{array}{l}\text { tail fiber protein, tail length } \\
\text { tape-measure protein, tail } \\
\text { assembly protein } \mathrm{K} \text { and } \mathrm{I} \text {, tail } \\
\text { attachment protein, tail } \\
\text { protein, tail terminator } \\
\text { protein, lipoprotein }\end{array}$ & $\begin{array}{l}\text { Caudovirales; Siphoviridae, } \\
\text { Pseudomonas phage phiAH14a, } \\
\text { complete genome, } 85 \% \text { identity }\end{array}$ & $\begin{array}{l}\text { Proteobacteria, } \\
\text { Gammaproteo-bacteria } \\
\text { (Pseudomonas sp.) }\end{array}$ & $\begin{array}{l}\text { Siphoviridae; } \\
1845.42\end{array}$ \\
\hline $\mathrm{H} 3$ & 1079 and 1 & $4431(226)$ & circular & major capsid protein & $\begin{array}{l}\text { O. Caudovirales, Fam Microviridae, } \\
68.92 \% \text { identity }\end{array}$ & Proteobacteria & $\begin{array}{l}\text { Microviridae; } \\
247.37\end{array}$ \\
\hline $\mathrm{H} 3$ & 1155 and 1 & 4188 (1772) & circular & $\begin{array}{l}\text { terminase, head } \\
\text { morphogenesis protein }\end{array}$ & $\begin{array}{l}\text { Myovirus (Uncultured Caudovirales } \\
\text { phage clone), } 76 \% \text { identity }\end{array}$ & $\begin{array}{l}\text { Proteobacteria, } \\
\text { Gammaproteo-bacteria } \\
\text { (Pseudomonas sp.) }\end{array}$ & $\begin{array}{l}\text { Siphoviridae; } \\
22.545\end{array}$ \\
\hline $\mathrm{H} 3$ & 300 and 2 & $10081(10275)$ & linear & $\begin{array}{l}\text { phage major tail sheath } \\
\text { protein, phage major tail tube } \\
\text { protein, phage tail protein } \mathrm{D} \\
\text { and } \mathrm{E}\end{array}$ & $\begin{array}{l}\text { O. Caudovirales; Fam Myoviridae; } \\
\text { Sub Fam Peduovirinae; Peduovirus; } \\
\text { unclassified Peduovirus, (Burkholderia } \\
\text { phage ST79) 92\% identity }\end{array}$ & $\begin{array}{l}\text { Proteobacteria, } \\
\text { Betaproteobacteria }\end{array}$ & $\begin{array}{l}\text { Peduovirinae; } \\
\quad 49.34\end{array}$ \\
\hline $\mathrm{H} 3$ & 449 and 2 & 8201 (7268) & linear & exonuclease, DNA primase & $\begin{array}{l}\text { O. Caudovirales; Siphoviridae; } \\
\text { Pahexavirus; unclassified } \\
\text { Pahexavirus, Propionibacterium phage } \\
\text { pa28, complete genome, } 92 \% \text { identity }\end{array}$ & Actinobacteria & $\begin{array}{l}\text { Siphoviridae; } \\
107.52\end{array}$ \\
\hline
\end{tabular}

${ }^{1}$ number in parenthesis $=$ size of the fragment that belongs to the viral identified sequence within the whole segment, NA = not available. 


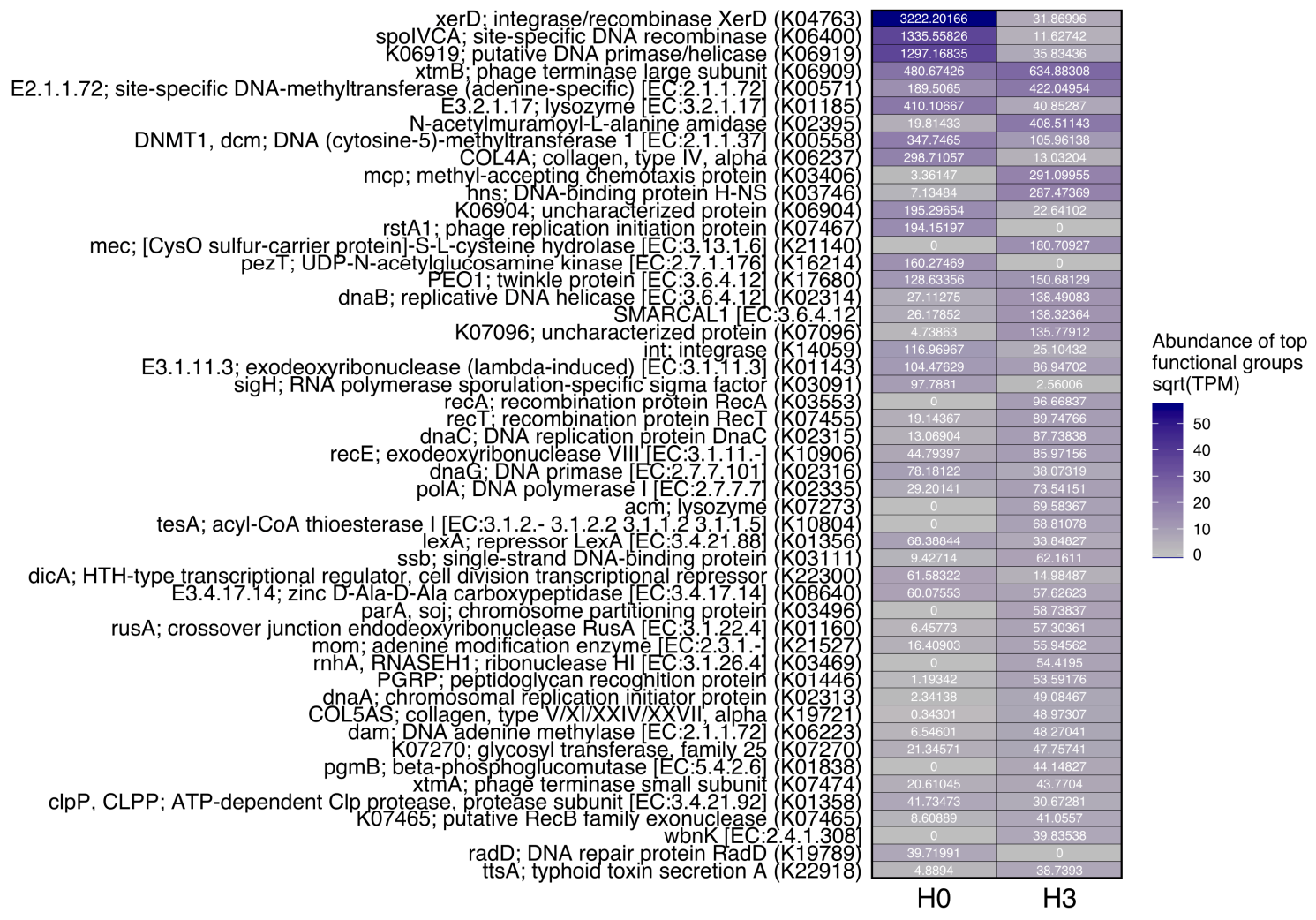

Figure 4. Viral genes heatmap generated with VIBRANT.

Many AMGs encoded by the viral communities also had differences in representation between the two sites (Figure 5). A cysteine hydrolase AMG enzyme highly abundant in $\mathrm{H} 3$ but absent in $\mathrm{H0}$ (cysO; [59]), along with the higher representation of the $\mathrm{H} 3$ autolysin enzymes mentioned above, supports the more lytic nature of phages in the $\mathrm{H} 3$ community during sampling.

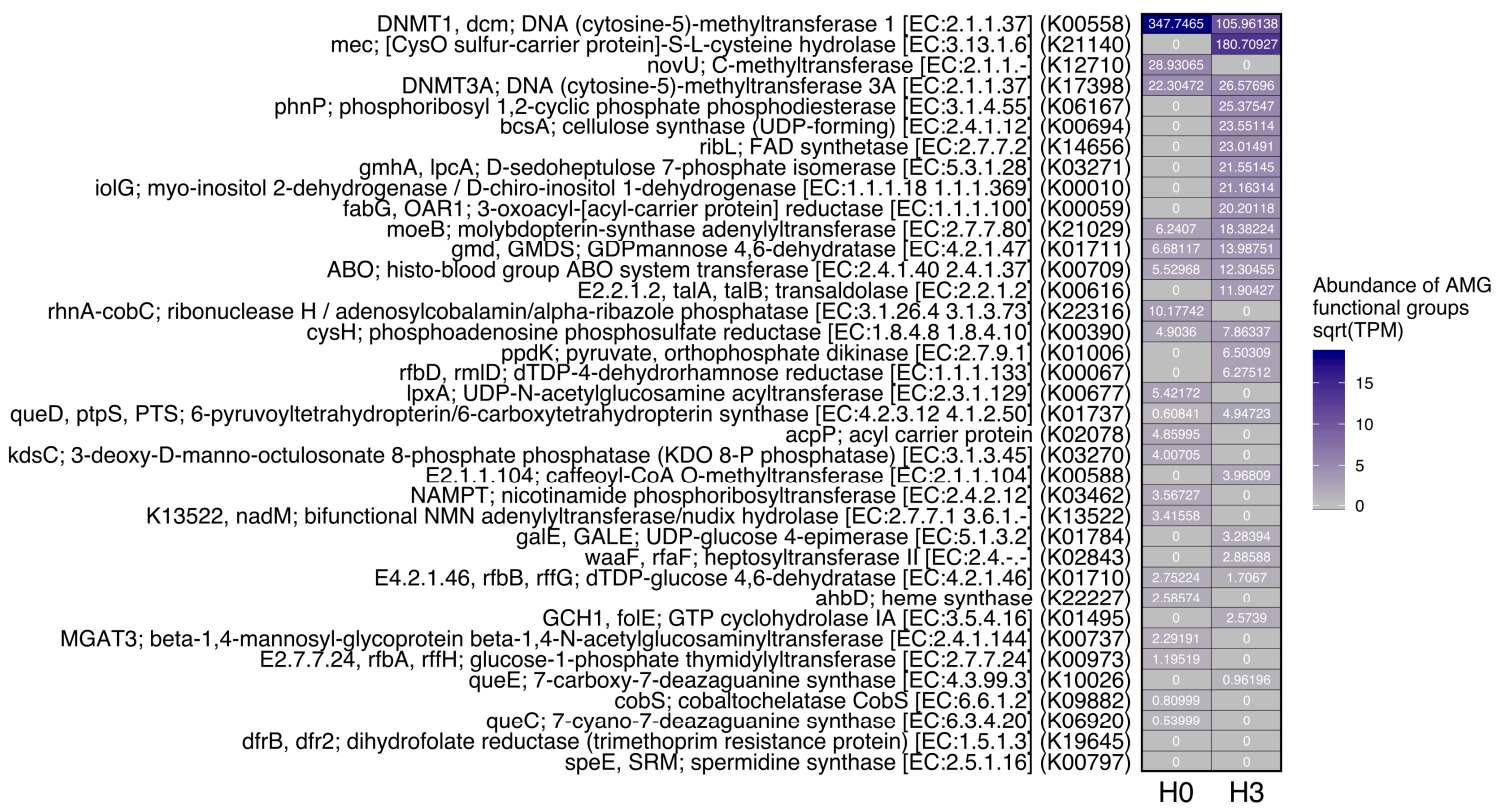

Figure 5. Viral auxiliary metabolic genes (AMGs) heatmap generated with VIBRANT.

Evidence shows that in freshwater environments, the relatively high availability of resources, such as carbon, nitrogen and phosphorus, seems to promote lytic cycles while the limitation of these 
elements produces lysogenic infection mechanisms [60,61]. In particular, when phosphorus is limited, lysis could be inhibited due to the paucity of phosphate to produce the backbone of the viral DNA structure [61,62]. In our study, phosphate concentration was 0.081 and $0.090 \mathrm{mg} \mathrm{L}^{-1}$ for $\mathrm{H} 0$ and $\mathrm{H} 3$, respectively which are similar to values reported earlier for this wetland [13,45] and are considered high for a freshwater environment [63]. This could indicate a more lytic nature in the infections occurring in the ponds studied. Although in both sites genes that encode for enzymes related to both types of replications mechanisms were found, in $\mathrm{H} 3$ the enzymes that participate in the wall cell degradation were much more abundant (Figure 4). In addition, in both sites, AMGs that encode for proteins that function in phosphate metabolism were found (e.g., phnP, gmhA, cysH, cobC and kdsC) (Figure 5). These types of genes have been also reported in other metagenomic studies in marine [64-66] and freshwater environments [56].

The viral replication mechanisms taking place in $\mathrm{H} 0$ and $\mathrm{H} 3$ could influence the way that microbial communities use carbon sources; for instance, during a lysogenic infection the host gene expression is modulated in such a way that its overall metabolism is reduced and the rate of inorganic and organic matter mineralization for growth is decreased $[67,68]$, which affects the bulk carbon cycle and turnover of local nutrients. Further, Bonetti et al. [69] suggested that lysogenic and lytic cycles could decrease microbial growth efficiency and lead the pool of sequestered carbon in freshwater wetlands to be emitted as greenhouse gases. Future research should focus on resolving questions related to the abiotic and/or biotic modulators of viral infection (e.g., temperature, nutrients availability, seasonality and microbial diversity), the impact of viral phase on biogeochemical cycles, and the role of viral infection pathways and AMGs in carbon use, recycling of the organic matter, and emission of stored greenhouse gases in this wetland. Combined knowledge of these fundamental mechanisms will contribute to a better understanding of ecology in this fragile but polyextreme high-altitude wetland.

\section{Conclusions}

The metagenomes analyzed in this study contained a high level of unclassified prokaryote sequences, suggesting a high microbial novelty. In addition, one half and one third of viral contigs in the $\mathrm{H} 0$ and $\mathrm{H} 3$ sites, respectively, could not be assigned to a known group based on sequence homology, suggesting a high level of novel viral groups present in this high-altitude wetland. We suggest that there are many unknown phage-prokaryote relationships in this polyextreme environment. Among known sequences, the bacteria domain was composed mainly of Proteobacteria and Bacteroidetes, and, also to a lesser extent, phyla such as Firmicutes and Cyanobacteria. These groups showed differential abundance between the sampled sites.

Genes that participate in lysogenic and lytic pathways were present in the metagenomes analyzed for both sites and suggest that an active phase of the lytic or lysogenic cycle was occurring during the sampling time (November 2015, dry season), especially in H0 site. In comparison, H3 presented AMGs that encoded cysteine hydrolase, which has a catalytic activity that indicates a higher potential for lytic activity in this site at the time of sampling.

Viruses are biological entities that balance energy and matter cycling through ecosystems, and the knowledge obtained about these entities in our study provide a better understanding of ecosystems in high-altitude wetlands subjected to extreme conditions like Salar de Huasco.

Supplementary Materials: Supplementary materials can be found at http://www.mdpi.com/2076-2607/8/7/ 1077/s1, Table S1: VIRSorter_global-phage-signal_H0, Table S2: VIRSorter_global-phage-signal_H3, Table S3: H0_vibrant_results_full, Table S4: H3_vibrant_results_full.

Author Contributions: Writing—original draft preparation was done by Y.E. and B.K.; Y.E., V.M. and C.D. designed the study; Y.E. and B.K. processed and analysis of the data; Y.E., V.M., C.D. and M.H. performed the field experiments; writing-review was done by Y.E., B.K., V.M., C.D. and M.H.; V.M. and C.D. provided the funds for the research. All the authors approved the final manuscript. All authors have read and agreed to the published version of the manuscript.

Funding: This research was funded by FONDECYT, grants numbers 1140179, 1171324 and 1181773 and “Concurso de Apoyo a la Participación en Estadías Académicas Cortas", UV, grant number R.E. No. 1876 de 2016 to Y.E. 
Acknowledgments: We are grateful to Melline Noronha and Ricardo Valencia for their technical support in data analysis. Y.E. is grateful of the genomic analysis training she received thanks to Forest Rohwer in the Rohwer \& Wegley-Kelly Lab, SDSU, USA. We also thank to Pedro and Margarita Luca for providing the host facilities at Salar de Huasco and Jaime Guerrero, for field assistance.

Conflicts of Interest: The authors declare no conflict of interest. The funders had no role in the design of the study; in the collection, analyses, or interpretation of data; in the writing of the manuscript, or in the decision to publish the results.

\section{References}

1. Ramsar Convention Secretariat. An Introduction to the Convention on Wetlands, 5th ed.; (Previously the Ramsar Convention Manual); Ramsar Convention Secretariat: Gland, Switzerland, 2016; ISBN 2-8317-0200-3.

2. Max Finlayson, C. Forty years of wetland conservation and wise use. Aquat. Conserv. Mar. Freshw. Ecosyst. 2012, 22, 139-143. [CrossRef]

3. Davidson, N. How much wetland has the world lost? Long-term and recent trends in global wetland area. Mar. Freshw. Res. 2014, 65, 936-941. [CrossRef]

4. Hu, S.; Niu, Z.; Chen, Y.; Li, L.; Zhang, H. Global wetlands: Potential distribution, wetland loss, and status. Sci. Total Environ. 2017, 586, 319-327. [CrossRef]

5. Dorador, C.; Vila, I.; Imhoff, J.F.; Witzel, K.P. Cyanobacterial diversity in Salar de Huasco, a high altitude saline wetland in northern Chile: An example of geographical dispersion? FEMS Microbiol. Ecol. 2008, 64, 419-432. [CrossRef] [PubMed]

6. Albarracín, V.H.; Kurth, D.; Ordoñez, O.F.; Belfiore, C.; Luccini, E.; Salum, G.M.; Piacentini, R.D.; Farías, M.E. High-up: A remote reservoir of microbial extremophiles in central Andean Wetlands. Front. Microbiol. 2015, 6, 1404. [CrossRef] [PubMed]

7. Dorador, C.; Vila, I.; Witzel, K.-P.; Imhoff, J.F. Bacterial and archaeal diversity in high altitude wetlands of the Chilean Altiplano. Fundam. Appl. Limnol. 2013, 182, 135-159. [CrossRef]

8. Molina, V.; Hernández, K.; Dorador, C.; Eissler, Y.; Hengst, M.; Pérez, V.; Harrod, C. Bacterial Active Community Cycling in Response to Solar Radiation and Their Influence on Nutrient Changes in a High-Altitude Wetland. Front. Microbiol. 2016, 7, 1-15. [CrossRef] [PubMed]

9. Molina, V.; Dorador, C.; Fernández, C.; Bristow, L.; Eissler, Y.; Hengst, M.; Hernandez, K.; Olsen, L.M.; Harrod, C.; Marchant, F.; et al. The activity of nitrifying microorganisms in a high-altitude Andean wetland. FEMS Microbiol. Ecol. 2018, 94, 1-13. [CrossRef] [PubMed]

10. Aceituno, P. Aspectos generales del clima en el Altiplano Sudamericano. In El Altiplano: Ciencia y Conciencia de los Andes, Actas del 21 Simposio Internacional de Estudios Altiplánicos; Charrier, R., Aceituno, P., Castro, M., Llanos, A., Raggi, L.A., Eds.; Universidad de Chile: Santiago, Chile, 1997; Volume 21, pp. 63-69.

11. Risacher, F.; Alonso, H.; Salazar, C. The origin of brines and salts in Chilean salars: A hydrochemical review. Earth Sci. Rev. 2003, 63, 249-293. [CrossRef]

12. Aguilar, P.; Acosta, E.; Dorador, C.; Sommaruga, R. Large differences in bacterial community composition among three nearby extreme waterbodies of the high Andean plateau. Front. Microbiol. 2016, 7. [CrossRef]

13. Eissler, Y.; Gálvez, M.J.; Dorador, C.; Hengst, M.; Molina, V. Active microbiome structure and its association with environmental factors and viruses at different aquatic sites of a high-altitude wetland. Microbiologyopen 2019, 8, 1-13. [CrossRef]

14. Dorador, C.; Vila, I.; Remonsellez, F.; Imhoff, J.F.; Witzel, K.P. Unique clusters of Archaea in Salar de Huasco, an athalassohaline evaporitic basin of the Chilean Altiplano. FEMS Microbiol. Ecol. 2010, 73, 291-302. [CrossRef] [PubMed]

15. Breitbart, M.; Bonnain, C.; Malki, K.; Sawaya, N.A. Phage puppet masters of the marine microbial realm. Nat. Microbiol. 2018, 3, 754-766. [CrossRef]

16. Hurwitz, B.L.; Hallam, S.J.; Sullivan, M.B. Metabolic reprogramming by viruses in the sunlit and dark ocean. Genome Biol. 2013, 14, R123. [CrossRef]

17. Anantharaman, K.; Duhaime, M.B.; Breier, J.A.; Wendt, K.A.; Toner, B.M.; Dick, G.J. Sulfur Oxidation Genes in Diverse Deep-Sea Viruses. Science (80-). 2014, 344, 757-760. [CrossRef] [PubMed]

18. Ahlgren, N.A.; Fuchsman, C.A.; Rocap, G.; Fuhrman, J.A. Discovery of several novel, widespread, and ecologically distinct marine Thaumarchaeota viruses that encode amoC nitrification genes. ISME J. 2019, 13, 618-631. [CrossRef] [PubMed] 
19. Castelán-Sánchez, H.G.; Lopéz-Rosas, I.; García-Suastegui, W.A.; Peralta, R.; Dobson, A.D.W.; Batista-García, R.A.; Dávila-Ramos, S. Extremophile deep-sea viral communities from hydrothermal vents: Structural and functional analysis. Mar. Genom. 2019, 46, 16-28. [CrossRef]

20. Wommack, K.E.; Colwell, R.R. Virioplankton: Viruses in aquatic ecosystems. Microbiol. Mol. Biol. Rev. 2000, 64, 69-114. [CrossRef]

21. Parikka, K.J.; Le Romancer, M.; Wauters, N.; Jacquet, S. Deciphering the virus-to-prokaryote ratio (VPR): Insights into virus-host relationships in a variety of ecosystems. Biol. Rev. 2017, 92, 1081-1100. [CrossRef]

22. Wigington, C.H.; Sonderegger, D.; Brussaard, C.P.D.; Buchan, A.; Finke, J.F.; Fuhrman, J.A.; Lennon, J.T.; Middelboe, M.; Suttle, C.A.; Stock, C.; et al. Re-examination of the relationship between marine virus and microbial cell abundances. Nat. Microbiol. 2016, 1. [CrossRef]

23. Jackson, E.F.; Jackson, C.R. Viruses in wetland ecosystems. Freshw. Biol. 2008, 53, 1214-1227. [CrossRef]

24. De Cárcer, D.A.; López-Bueno, A.; Pearce, D.A.; Alcamí, A. Biodiversity and distribution of polar freshwater DNA viruses. Sci. Adv. 2015, 1. [CrossRef] [PubMed]

25. Roux, S.; Enault, F.; Robin, A.; Ravet, V.; Personnic, S.; Theil, S.; Colombet, J.; Sime-Ngando, T.; Debroas, D. Assessing the diversity and specificity of two freshwater viral communities through metagenomics. PLoS ONE 2012, 7, e33641. [CrossRef] [PubMed]

26. Li, J.K.; Sun, C.; Li, S.; Cui, Y.S.; Wei, Y.L.; Ji, X.L. Genetic Diversity of Bacteriophage Communities in Napahai Wetland. In Proceedings of the International Conference on Industrial Electronics and Applications (IEA 2015), Paris, France, 27-28 June 2015. [CrossRef]

27. Xiang, Y.; Wang, S.; Li, J.; Wei, Y.; Zhang, Q.; Lin, L.; Ji, X. Isolation and characterization of two lytic cold-active bacteriophages infecting Pseudomonas fluorescens from the Napahai plateau wetland. Can. J. Microbiol. 2017, 64, 183-190. [CrossRef] [PubMed]

28. Qin, K.; Ji, X.; Zhang, C.; Ding, Y.; Kuang, A.; Zhang, S.; Zhang, Q.; Lin, L.; Wei, Y. Isolation and characterization of wetland VSW-3, a novel lytic cold-active bacteriophage of Pseudomonas fluorescens. Can. J. Microbiol. 2016, 63, 110-118. [CrossRef]

29. Roux, S.; Hallam, S.J.; Woyke, T.; Sullivan, M.B. Viral dark matter and virus-host interactions resolved from publicly available microbial genomes. Elife 2015, 4, 1-20. [CrossRef]

30. Kieft, K.; Zhou, Z.; Anantharaman, K. VIBRANT: Automated recovery, annotation and curation of microbial viruses, and evaluation of virome function from genomic sequences. bioRxiv 2019, 855387. [CrossRef]

31. Atlas, E.L.; Gordon, L.I.; Hager, S.W.; Park, P.K. A Practical Manual for Use of the Technicon AutoAnalyzer in Seawater Nutrient Analyses (Revised); Tech. Rep. 215; Department of Oceanography, School of Science, Oregon State University: Corvallis, OR, USA, 1971.

32. Chen, F.; Lu, J.-R.; Binder, B.J.; Liu, Y.-C.; Hodson, R.E. Application of Digital Image Analysis and Flow Cytometry To Enumerate Marine Viruses Stained with SYBR Gold Application of Digital Image Analysis and Flow Cytometry To Enumerate Marine Viruses Stained with SYBR Gold. Appl. Environ. Microbiol. 2001, 67, 539-545. [CrossRef]

33. Wommack, K.E.; Sime-Ngando, T.; Winget, D.M.; Jamindar, S.; Helton, R.R. Filtration-based methods for the collection of viral concentrates from large water samples. In Manual of Aquatic Viral Ecology; American Society of Limnology and Oceanography: Waco, TX, USA, 2010; pp. 110-117, ISBN 9780984559107.

34. Colombet, J.; Robin, A.; Lavie, L.; Bettarel, Y.; Cauchie, H.M.; Sime-Ngando, T. Virioplankton "pegylation": Use of PEG (polyethylene glycol) to concentrate and purify viruses in pelagic ecosystems. J. Microbiol. Methods 2007, 71, 212-219. [CrossRef]

35. Lasken, R.S. Genomic DNA amplification by the multiple displacement amplification (MDA) method. Biochem. Soc. Trans. 2009, 37, 450-453. [CrossRef]

36. Bolger, A.M.; Lohse, M.; Usadel, B. Trimmomatic: A flexible trimmer for Illumina sequence data. Bioinformatics 2014, 30, 2114-2120. [CrossRef] [PubMed]

37. Nurk, S.; Bankevich, A.; Antipov, D.; Gurevich, A.A.; Korobeynikov, A.; Lapidus, A.; Prjibelski, A.D.; Pyshkin, A.; Sirotkin, A.; Sirotkin, Y.; et al. Assembling single-cell genomes and mini-metagenomes from chimeric MDA products. J. Comput. Biol. 2013, 20, 714-737. [CrossRef] [PubMed]

38. Hyatt, D.; Chen, G.L.; LoCascio, P.F.; Land, M.L.; Larimer, F.W.; Hauser, L.J. Prodigal: Prokaryotic gene recognition and translation initiation site identification. BMC Bioinforma 2010, 11. [CrossRef] [PubMed]

39. Langmead, B.; Salzberg, S. Bowtie2. Nat. Methods 2013, 9, 357-359. [CrossRef] 
40. Wagner, G.P.; Kin, K.; Lynch, V.J. Measurement of mRNA abundance using RNA-seq data: RPKM measure is inconsistent among samples. Theory Biosci. 2012, 131, 281-285. [CrossRef]

41. Buchfink, B.; Xie, C.; Huson, D.H. Fast and sensitive protein alignment using DIAMOND. Nat. Methods 2015, 12,59-60. [CrossRef]

42. Kanehisa, M.; Sato, Y.; Morishima, K. BlastKOALA and GhostKOALA: KEGG Tools for Functional Characterization of Genome and Metagenome Sequences. J. Mol. Biol. 2016, 428, 726-731. [CrossRef]

43. Oksanen, J.; Blanchet, F.G.; Friendly, M.; Kindt, R.; Legendre, P.; McGlinn, D.; Minchin, P.R.; O'Hara, R.B.; Simpson, G.L.; Solymos, P.; et al. Vegan: Community Ecology Package. R package Version 2.5-4; R Development Core Team: Vienna, Austria, 2019.

44. Cowardin, L.M.; Carter, V.; Golet, F.C.; LaRoe, E.T. Classification of Wetlands and Deepwater Habitats of the United States; U.S. Department of the Interior Fish and Wildlife Service Office of Biological Services: Washington, DC, USA, 1979.

45. Molina, V.; Eissler, Y.; Cornejo, M.; Galand, P.E.; Dorador, C.; Hengst, M.; Fernandez, C.; Francois, J.P. Distribution of greenhouse gases in hyper-arid and arid areas of northern Chile and the contribution of the high altitude wetland microbiome (Salar de Huasco, Chile). Antonie Leeuwenhoek Int. J. Gen. Mol. Microbiol. 2018, 111, 1421-1432. [CrossRef]

46. Weinbauer, M.G. Ecology of prokaryotic viruses. FEMS Microbiol. Rev. 2004, 28, 127-181. [CrossRef]

47. Clasen, J.L.; Brigden, S.M.; Payet, J.P.; Suttle, C.A. Evidence that viral abundance across oceans and lakes is driven by different biological factors. Freshw. Biol. 2008, 53, 1090-1100. [CrossRef]

48. Hernández, K.L.; Yannicelli, B.; Olsen, L.M.; Dorador, C.; Menschel, E.J.; Molina, V.; Remonsellez, F.; Hengst, M.B.; Jeffrey, W.H. Microbial activity response to solar radiation across contrasting environmental conditions in Salar de Huasco, northern Chilean altiplano. Front. Microbiol. 2016, 7, 1-13. [CrossRef]

49. Sommaruga, R.; Obernosterer, I.; Herndl, G.J.; Psenner, R. Inhibitory effect of solar radiation on thymidine and leucine incorporation by freshwater and marine bacterioplankton. Appl. Environ. Microbiol. 1997, 63, 4178-4184. [CrossRef] [PubMed]

50. Eiler, A.; Bertilsson, S. Composition of freshwater bacterial communities associated with cyanobacterial blooms in four Swedish lakes. Environ. Microbiol. 2004, 6, 1228-1243. [CrossRef]

51. Sarmento, H.; Casamayor, E.O.; Auguet, J.-C.; Vila-Costa, M.; Felip, M.; Camarero, L.; Gasol, J.M. Microbial food web components, bulk metabolism, and single-cell physiology of piconeuston in surface microlayers of high-altitude lakes. Front. Microbiol. 2015, 6, 361. [CrossRef] [PubMed]

52. Lasken, R.S.; Stockwell, T.B. Mechanism of chimera formation during the Multiple Displacement Amplification reaction. BMC Biotechnol. 2007, 7, 1-11. [CrossRef]

53. Bruder, K.; Malki, K.; Cooper, A.; Sible, E.; Shapiro, J.W.; Watkins, S.C.; Putonti, C. Freshwater metaviromics and bacteriophages: A current assessment of the state of the art in relation to Bioinformatic challenges. Evol. Bioinforma. 2016, 12, 25-33. [CrossRef] [PubMed]

54. Pietilä, M.K.; Atanasova, N.S.; Oksanen, H.M.; Bamford, D.H. Modified coat protein forms the flexible spindle-shaped virion of haloarchaeal virus His1. Environ. Microbiol. 2013, 15, 1674-1686. [CrossRef]

55. Skvortsov, T.; De Leeuwe, C.; Quinn, J.P.; McGrath, J.W.; Allen, C.C.R.; McElarney, Y.; Watson, C.; Arkhipova, K.; Lavigne, R.; Kulakov, L.A. Metagenomic characterisation of the viral community of lough neagh, the largest freshwater lake in Ireland. PLOS ONE 2016, 11, e150361. [CrossRef]

56. Menouni, R.; Hutinet, G.; Petit, M.A.; Ansaldi, M. Bacterial genome remodeling through bacteriophage recombination. FEMS Microbiol. Lett. 2015, 362, 1-10. [CrossRef]

57. Prigozhin, D.M.; Mavrici, D.; Huizar, J.P.; Vansell, H.J.; Alber, T. Structural and Biochemical Analyses of Mycobacterium tuberculosis N-Acetylmuramyl-1-alanine Amidase Rv3717 Point to a Role in Peptidoglycan Fragment Recycling. J. Biol. Chem. 2013, 288, 31549-31555. [CrossRef]

58. Kumar, A.; Kumar, S.; Kumar, D.; Mishra, A.; Dewangan, R.P.; Shrivastava, P.; Ramachandran, S.; Taneja, B. The structure of Rv3717 reveals a novel amidase from Mycobacterium tuberculosis. Acta Crystallogr. Sect. D 2013, 69, 2543-2554. [CrossRef] [PubMed]

59. Donovan, D.M.; Foster-Frey, J.; Dong, S.; Rousseau, G.M.; Moineau, S.; Pritchard, D.G. The Cell Lysis Activity of the Streptococcus agalactiae Bacteriophage B30 Endolysin relies on the Cysteine, Histidine-Dependent Amidohydrolase/Peptidase Domain. Appl. Environ. Microbiol. 2006, 72, 5108-5112. [CrossRef] [PubMed]

60. Wilson, W.H.; Mann, N.H. Lysogenic and lytic viral production in marine microbial communities. Aquat. Microb. Ecol. 1997, 13, 95-100. [CrossRef] 
61. Pradeep Ram, A.S.; Sime-Ngando, T. Resources drive trade-off between viral lifestyles in the plankton: Evidence from freshwater microbial microcosms. Environ. Microbiol. 2010, 12, 467-479. [CrossRef] [PubMed]

62. Thomas, R.; Berdjeb, L.; Sime-Ngando, T.; Jacquet, S. Viral abundance, production, decay rates and life strategies (lysogeny versus lysis) in Lake Bourget (France). Environ. Microbiol. 2011, 13, 616-630. [CrossRef]

63. Carlson, R.E. A trophic state index for lakes. Limnol. Oceanogr. 1977, 22, 361-369. [CrossRef]

64. Sullivan, M.B.; Coleman, M.L.; Weigele, P.; Rohwer, F.; Chisholm, S.W. Three Prochlorococcus cyanophage genomes: Signature features and ecological interpretations. PLoS Biol. 2005, 3, e144. [CrossRef]

65. Breitbart, M. Marine viruses: Truth or dare. Ann. Rev. Mar. Sci. 2012, 4. [CrossRef]

66. Zimmerman, A.E.; Howard-Varona, C.; Needham, D.M.; John, S.G.; Worden, A.Z.; Sullivan, M.B.; Waldbauer, J.R.; Coleman, M.L. Metabolic and biogeochemical consequences of viral infection in aquatic ecosystems. Nat. Rev. Microbiol. 2020, 18, 21-34. [CrossRef]

67. Chen, Y.; Golding, I.; Sawai, S.; Guo, L.; Cox, E.C. Population fitness and the regulation of Escherichia coli genes by bacterial viruses. PLoS Biol. 2005, 3, e229. [CrossRef]

68. Paul, J.H. Prophages in marine bacteria: Dangerous molecular time bombs or the key to survival in the seas? ISME J. 2008, 2, 579. [CrossRef] [PubMed]

69. Bonetti, G.; Trevathan-Tackett, S.M.; Carnell, P.E.; Macreadie, P.I. Implication of viral infections for greenhouse gas dynamics in freshwater wetlands: Challenges and perspectives. Front. Microbiol. 2019, 10. [CrossRef] [PubMed]

(C) 2020 by the authors. Licensee MDPI, Basel, Switzerland. This article is an open access article distributed under the terms and conditions of the Creative Commons Attribution (CC BY) license (http://creativecommons.org/licenses/by/4.0/). 